\title{
Mobile Based Application of Document Delivery (Case Study: PT Waindo Specterra)
}

\author{
Helda Fitriana Sari \\ Faculty of Computer Science \\ Mercu Buana University \\ Jakarta, Indonesia
}

\author{
Nur Ismawati \\ Faculty of Computer Science \\ Mercu Buana University \\ Jakarta, Indonesia
}

\begin{abstract}
The document delivery process at PT Waindo SpecTerra is still running manually. Problems arising from road documents that have been received need to be inputted into digital format by admin, travel documents are lost and not stored properly, so that entry data process by admin becomes disrupted. The purpose of this study are the availability of a mobile application that facilitates Company Admin and Driver in sending documents process, data delivery history that's directly stored in the database, and backup data in a structured database. This application uses the PHP programming language, HTML, MySQL Database, and Apache Cordova technology in the development of mobile-based systems. The research method used are library method, observation method and documentation method. The final researches are expected to provide an application system that can facilitate the process of sending documents at PT Waindo SpecTerra, so the road history data is more structured and backup data is available.
\end{abstract}

Keywords: Document Delivery, Mobile Based Application, Google Maps Direction, Apache Cordova

\section{INTRODUCTION}

Rapid technological development in the development of hardware and software and communication technology has become an alternative for a company to support operational activities. The development of information technology in the company has made changes in the procedures of operational activities from manuals to an integrated system. Time and cost efficiency make entrepreneurs need to apply technology in their companies.

PT Waindo SpecTerra is a national company engaged in consulting services in providing natural resource management solutions both land and sea supported by digital technology. One of the company's operational activities is correspondence administration activities. For companies, correspondence is the main activity to strengthen relations with other companies and requests for user requirements that must be met by consultant services.

The concept of sending physical documents that are already running at PT Waindo SpecTerra is that company's driver delivers the document to the destination location, then the recipient signs a delivery order as evidence that document has been received well, after that company's driver reports the delivery order to company's admin as a report delivery.

The problem that arises with this manual method are the delivery document that has been received needs to be inputted into a digital format by the admin as a report to the company's supervisor so that it is more neat and structured, so it requires more time and admin staff. Another problems are drivers are not responsible for delivering documents properly, such as mail order orders lost, dirty because of rain or not properly stored evidence of delivery documents, so that the data entry process by the admin is disturbed.

Based on the problem, the authors propose making "Mobile Based Application Of Document Delivery (Case Study: PT Waindo SpecTerra)".

\section{LITERATURE REVIEW 2.1. Mobile Application}

The mobile application is software that runs on mobile devices such as smartphones or tablet PCs. The mobile application is also known as an application that can be downloaded and has certain functions that add to the functionality of the device [1].

\subsection{Google Maps}

According to [2] Google Maps is a free service from Google that is quite popular. Users can add the Google Maps feature on the web with the Google Maps API. Google Maps API is a JavaScript library. The use of Google Maps API can save time and money to build reliable digital map applications, so users can focus only on the data needed.

\subsection{Apache Cordova}

According to [3] Apache Cordova is the main framework for building cellular applications for several target platforms using HTML5 (HTML, JavaScript, and CSS). When a smartphone or tablet user plays a device running a web or Cordova application, the browser must be able to react to changes and adjust page properties. Otherwise, when the browser window switches from portrait to landscape, some of the available screens will not be used.

\subsection{Company Document}

According to [4], Company documents are data, records, and or information that are made and or received by company in the context of carrying out their activities, whether written on paper or other means or recorded in the form of any pattern that can be seen, read or heard. 


\subsection{Goods Delivery Service}

According to (Moenir, 2006) in [5] Goods delivery service is an activity carried out by a person or group of people on the basis of material factors through certain systems, procedures and methods in the context of efforts to meet the interests of others in accordance with their rights.

\subsection{Related Research}

Research related of goods delivery have been carried out by several researchers from various perspectives, as follows [5]-[9],

Research by [5] provide an illustration that the process of making goods delivery reports is still manual so that the construction of a system that uses a computerized system is expected to provide better service, especially in terms of information needs. The goal is that employees do not have misunderstandings in processing data and there is no delay in goods delivery. The research methods used are library studies, field studies, and system development with the waterfall method.

Research by [6] explain design web-based information systems of goods delivery services to minimize the obstacles faced in the delivery of goods and services. The system design method used with the data flow diagram (DFD) method. The expected results help when logging in, or monitoring the effectiveness of the goods when the shipment takes place.

Research by [7] explained about VRP software that utilizes API services from Google Map capable of displaying maps, obtaining distance data, route data, and route depiction. The CVRP method uses the Sequential Insertion route search strategy.

Research by [8] provide an overview of online driver mobile application software on the android platform has helped drivers to get orders, help PT. XYZ to find out drivers who are ready to receive orders, and help customers place orders for cars and order drivers according to their choice.

Research by [9] explain Android-based application of tracking position goods delivery. This application purpose that couriers can log into application and can use each menu that is intended for couriers, process of selecting order of goods to be sent can run well, the process when courier updates the order status of goods can run well, a history page can display goods orders what has been done, courier can manage the profile data, and customer can track courier position when order status is in progress.

\section{RESEARCH METHOD}

\subsection{Research Location}

The research location at PT Waindo SpecTerra located on J1. Pejaten Raya No.2, Pejaten Raya Office Complex 7-8, RT1 / RW7, Pejaten Barat, Pasar Minggu, South Jakarta City, Jakarta Special Capital Region 12510.

\subsection{Software and Hardware}

3.2.1. The hardware used are:

1. Laptop set of Acer Aspire V5 431 with specification:

- Operating System = Windows 8.1 Pro 2013 Microsoft Corporation

- $\quad$ Processor System $=$ Intel ${ }^{\circledR}$ Core $^{\mathrm{TM}}$ i33217U CPU @ 1.80GHz

- $\quad$ Installed Memory $(\mathrm{RAM})=4.00 \mathrm{~GB}$ (3.80 GB usable)

- $\quad$ System type $=$ 64-bit Operating System, x64 based processor

2. Smartphone Vivo V7 series with specification:

- Android Version $=7.1 .2 \quad$ (Android Nougat)

- Processor $=1.8 \mathrm{GHz}$ Snapdragon Octacore

$-\quad \mathrm{RAM}=4 \mathrm{~GB}$

3. Printer set Canon IP 2770 series as a tool of printing document

4. Scanner as a tool to move printed documents into digital format

\subsubsection{The software used are:}

1. PHP MyAdmin within MySQL database

2. Microsoft Office for making final report

3. Sublime Text for writing source code

4. Mozilla Firefox to run HTML files

5. Web Server $=$ localhost

6. Adobe Photoshop and Balsamiq for making interface design

Research flow diagrams of Mobile Based Application of Document Delivery (Case Study: PT Waindo Specterra), as illustrated below: 


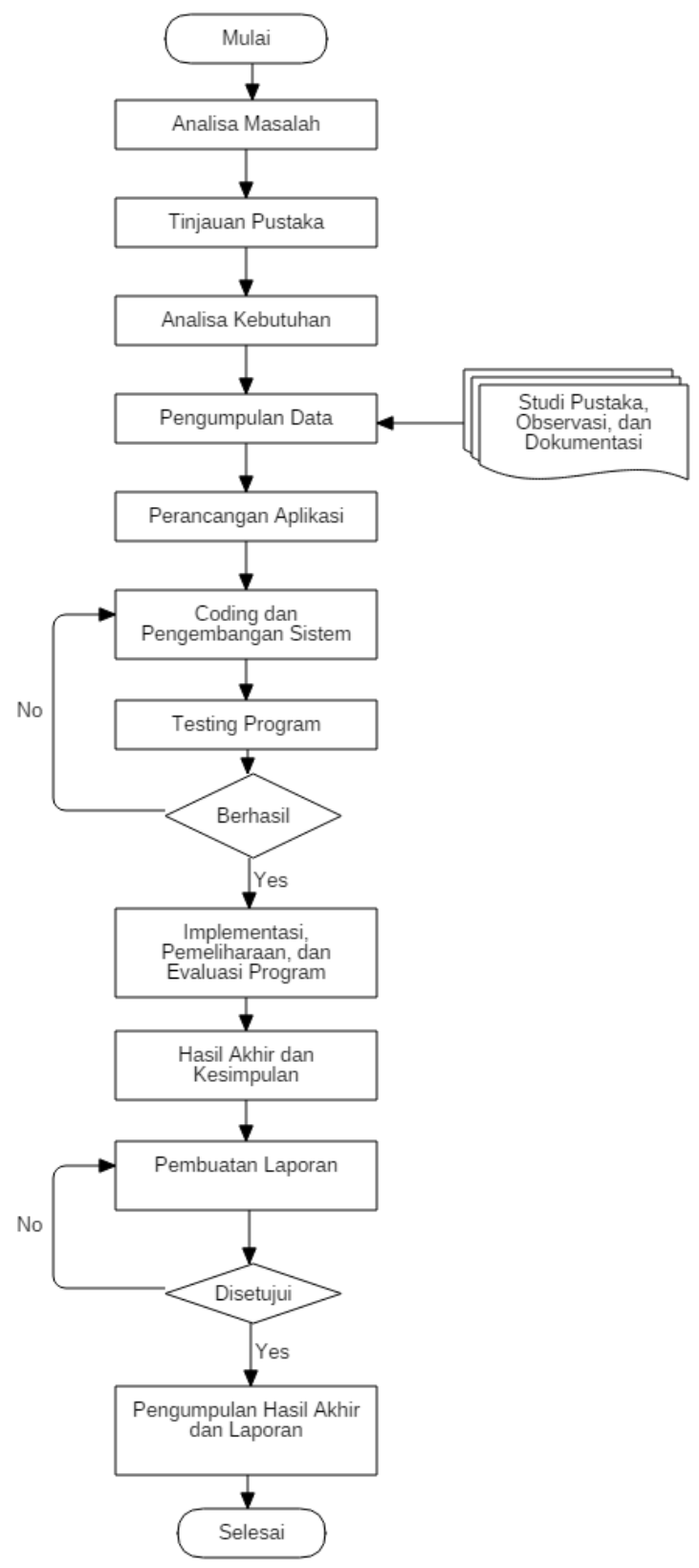

Figure 1. Research Flow Diagram

Explanation of each research stage are,

\section{Problem Analysis}

This stage identifies problems that must be solved based on the questions that arise, then analyzes the core of the problem, the cause of the problem, and the right solution to fix or resolve the problem.

2. Literature Review

This stage determines thoughts and theories that will be used as the basis for conducting research, then explains critical analysis of the relationship between journal articles from previous researchers and research that will be analyzed.

\section{Needs Analysis}

The needs analysis stage is the stage of determining features, constraints and objectives of the system in consultation with system users which are then defined in detail and function as system specifications.

4. Data Collection

Data collection is carried out to obtain information needed in order to achieve the research objectives. Data collection techniques used in this study are library study techniques, direct observation techniques, and documentation techniques.

5. Application Design

Application design stages allocate system requirements both software and hardware by forming the overall system architecture. The system architecture design and modeling phase focuses on data structure design, software architecture, interface display, and program algorithms.

6. Coding and System Development

The coding phase translates the logic requirements from pseudocode or flowchart into a programming language both the letters, numbers, and symbols that make up the program.

7. Testing Program

At this stage each program unit will be integrated with each other and tested as a complete system to ensure the system meets the existing requirements System testing carried out is black box testing.

8. Implementation, Maintenance and Evaluation Program

This stage implements software to the customer, periodic software maintenance, software repair, software evaluation, and software development based on feedback provided so that the system can continue to run and develop according to its function.

9. Report Documents and Collection of Final Results The report document is made as documentation research. The main purpose is written evidence about the results analysis that has been carried out The next stage is the final result of application that has been built in accordance with the specifications and report documents approved. 


\section{RESULT AND DISCUSSION}

Development research of Mobile Based Application of Document Delivery in PT Waindo SpecTerra designed with Unified Modelling Language (UML) and User Interface (UI) Design.

\subsection{Use Case Diagram}

The Use Case Diagram describes the activities that can be performed by system users in the application as shown in Figure 2.

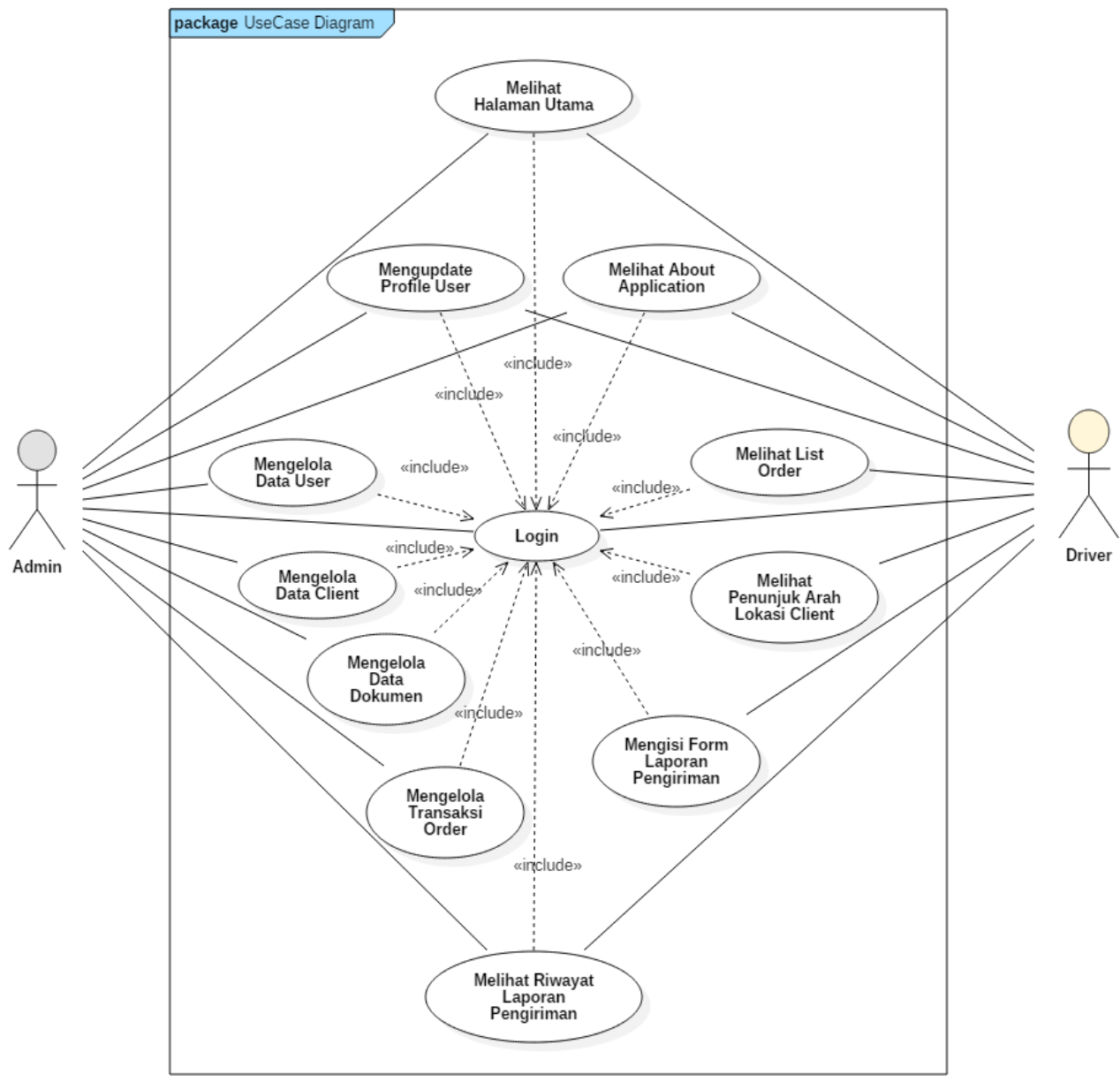

Figure 2. Use Case Diagram Application

Login activity is the initial stage to be able to access the application in full, the User enters a username and password. Activity views the main page is User (Admin and Driver) seeing information related to the company profile. Activity views about application is User (Admin and Driver) seeing information related to the application. Activity changes user profile is User (Admin and Driver) updates personal data that has been previously stored in the application. Activity manages user data is Admin manages user data, such as adding users (admin and driver) that have not been registered, updating user information and deleting user data. Activity manages client's data is Admin manages client's data, such as adding clients that have not been registered, updating client information and deleting client's data. Activitiy manages document is Admin manages document, such as adding document information to be sent to client, updating stored document information and deleting document. Activity manages order transaction data is Admin manages order transaction data, such as adding order information that must be sent to client, updating information on order documents and deleting document delivery orders. Activity views list order is driver seeing the detailed order data for sending documents that must be sent to client. Activity views direction of client location is Driver selects the Directions button so he can see the fastest alternative route to company's client location. Activity fills out delivery order form is Driver fills out document delivery report, then he uploads order photo received by the recipient. Activity views delivery report history is User seeing the delivery report resume by printing the delivery report form, the document will appear in the pdf viewer. 


\subsection{Class Diagram}

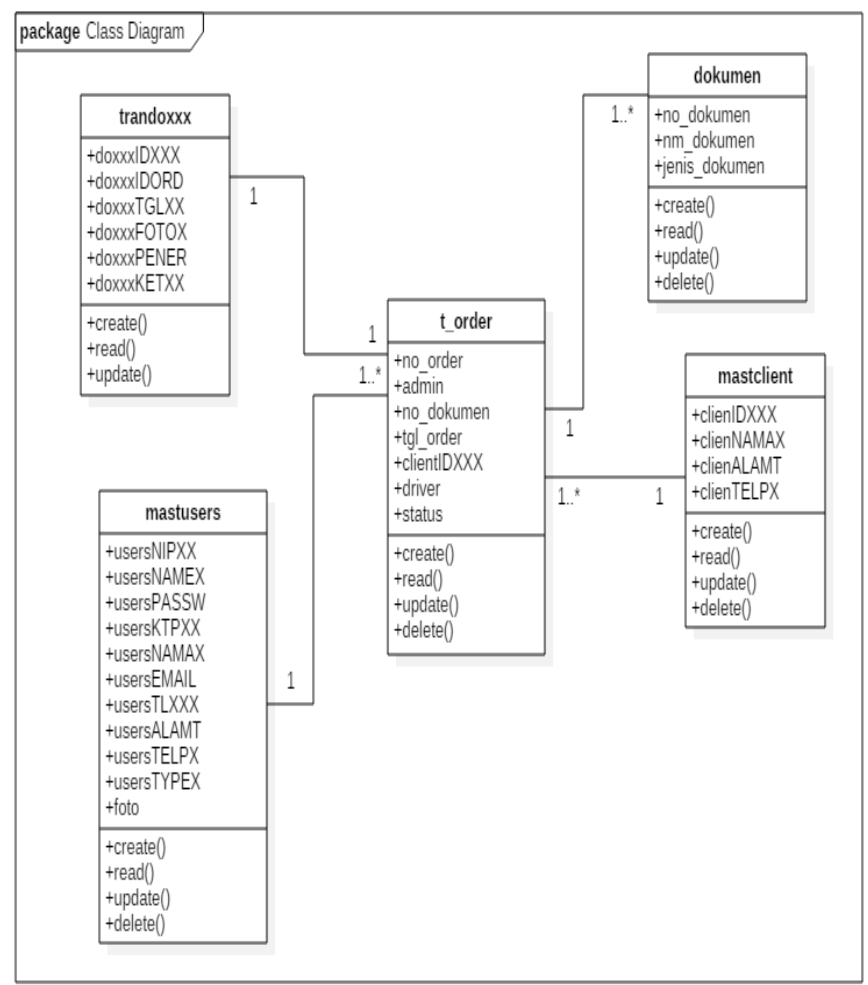

Figure 3. Class Diagram
4.3 Activity Diagram

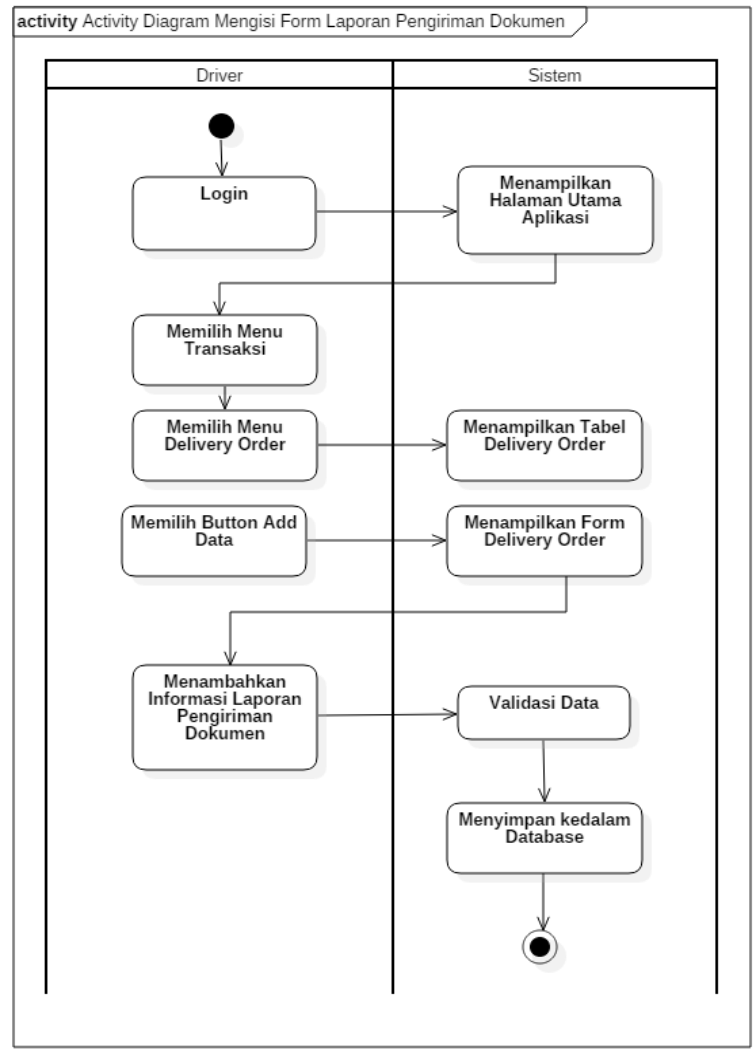

Figure 4. Activity Diagram Fill Out Delivery Report

\subsection{Sequence Diagram}

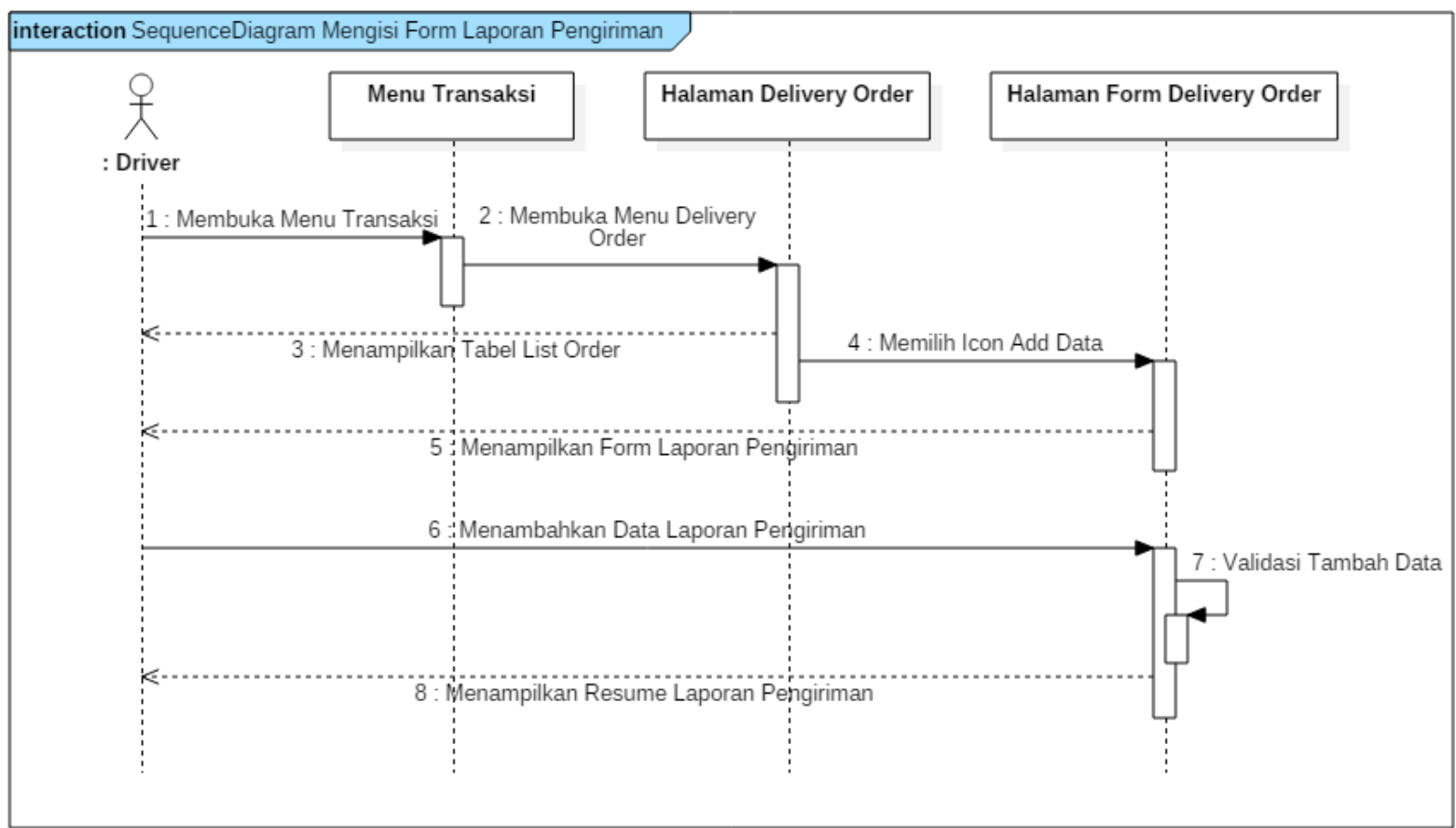

Figure 5. Sequence Diagram Fill Out Delivery Report 


\subsection{User Interface Design}

User interface designs of mobile-based application of

document delivery that will be created are:

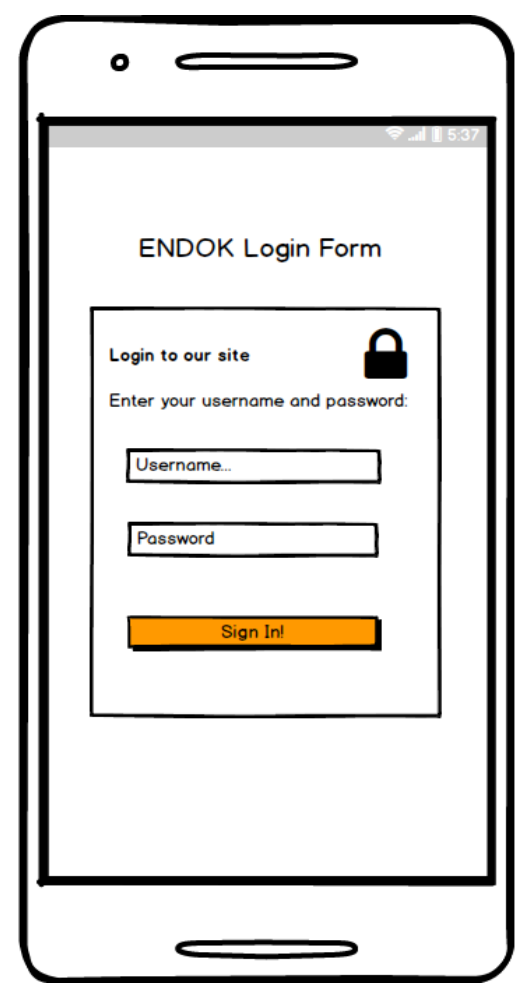

Figure 6. User Interface Login Form

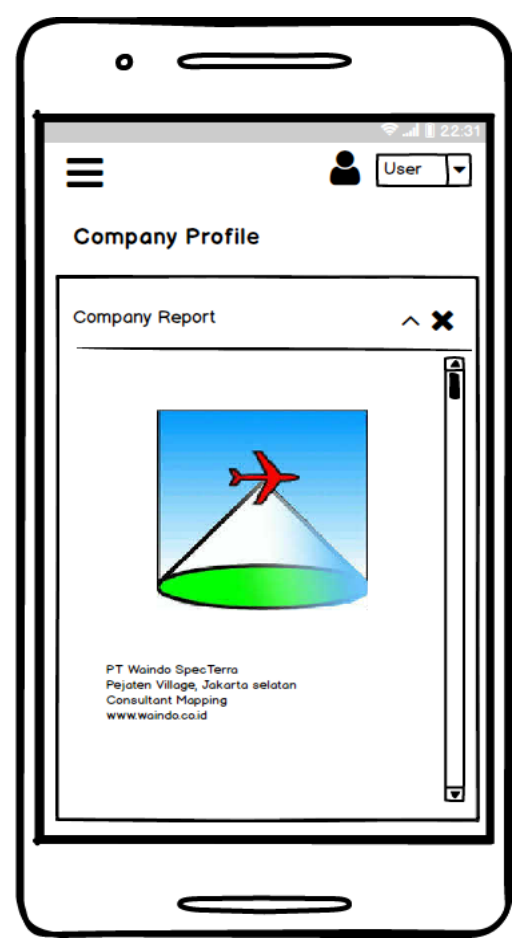

Figure 7. User Interface Main Page Application

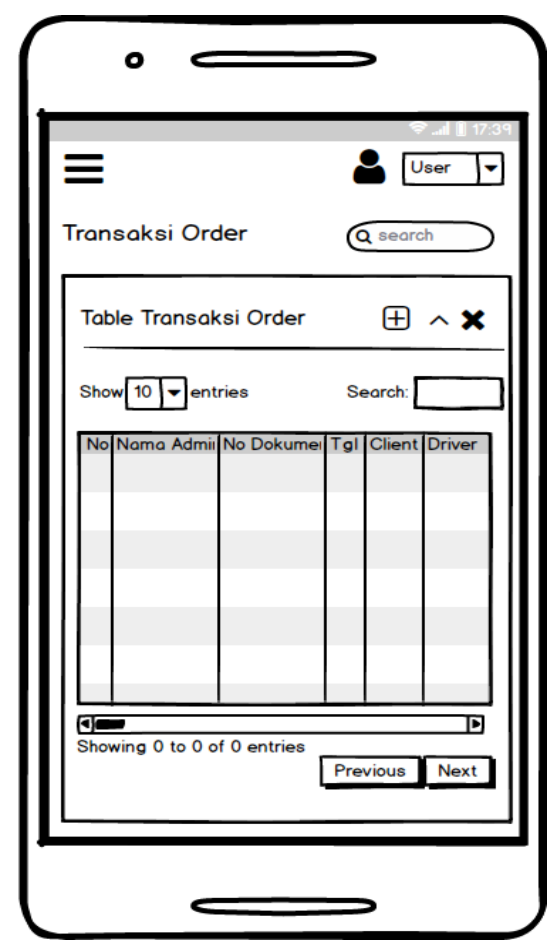

Figure 8. User Interface Order Transaction Page

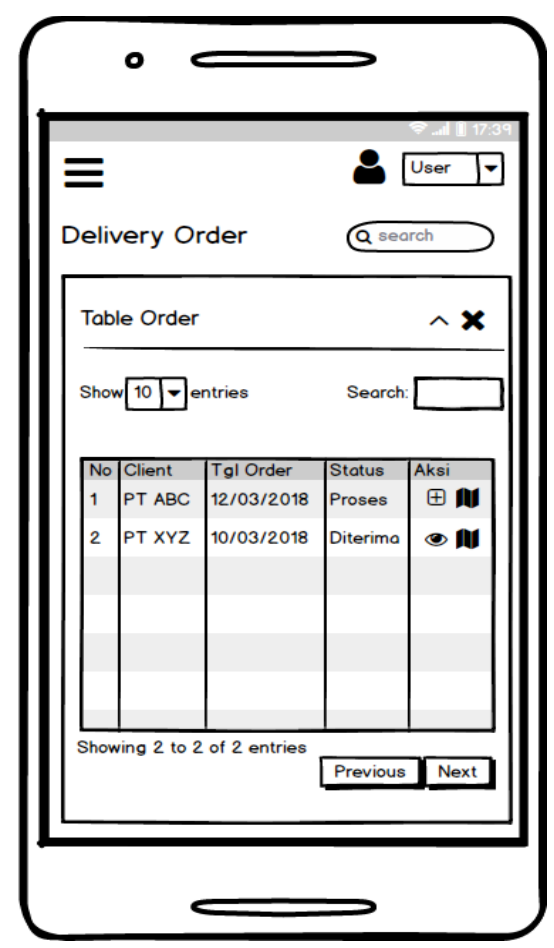

Figure 9. User Interface Delivery Order Page 


\subsection{Implementation Program}

The results of display implementation based on the analysis and design of previous display design are:

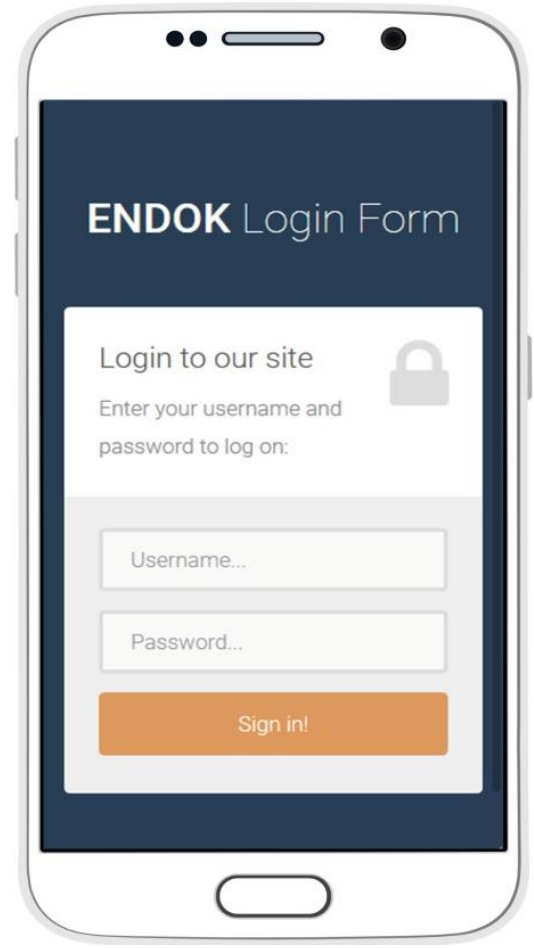

Figure 10. Implementation of Login Form

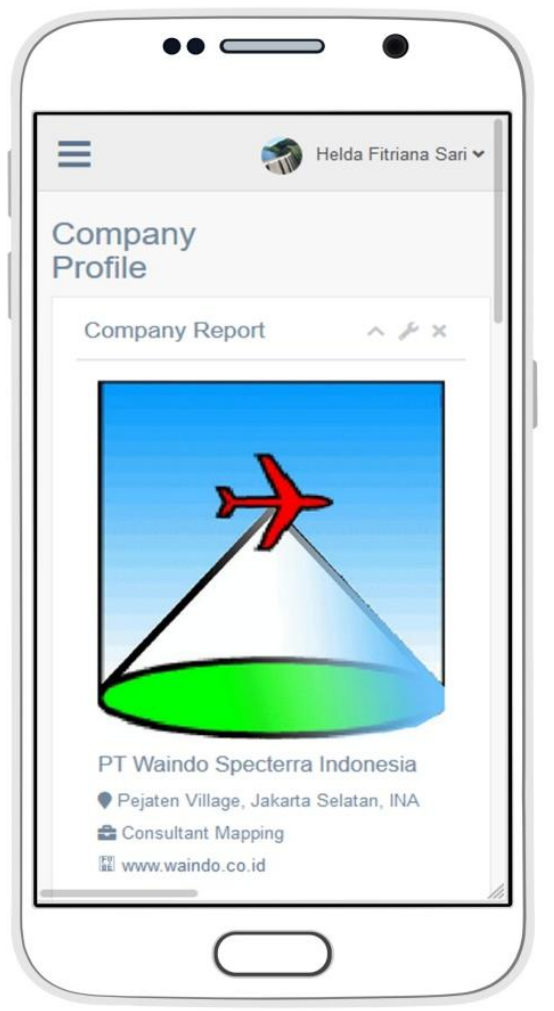

Figure 11. Implementation of Main Page Application

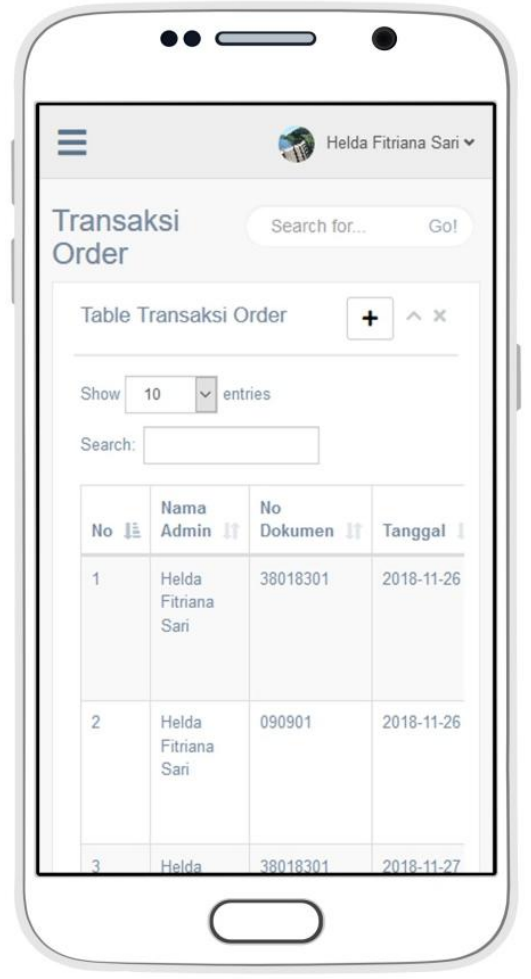

Figure 12. Implementation of Order Transaction Page

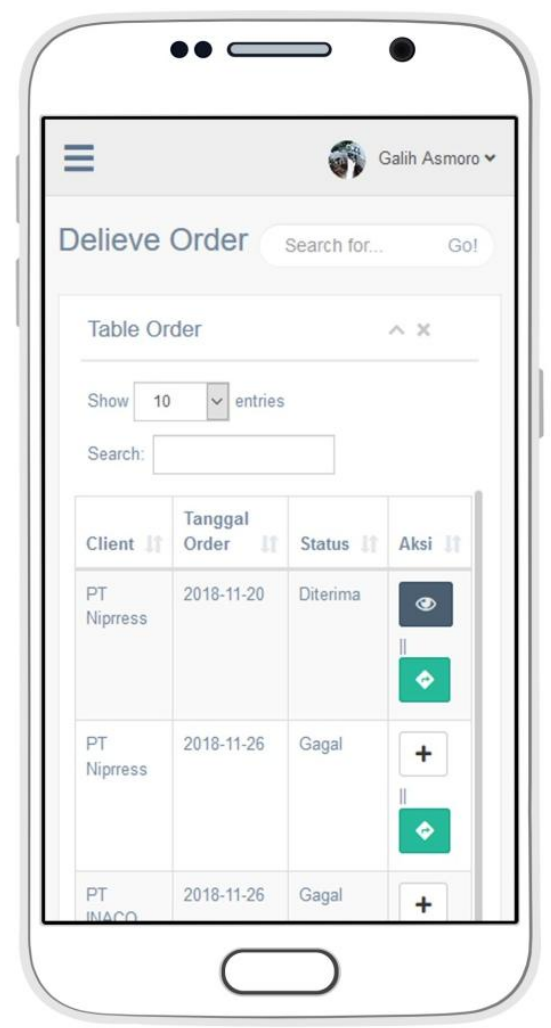

Figure 13. Implementation of Delivery Order Page 


\section{CONCLUSIONS AND SUGGESTIONS 5.1. Conclusions}

1. Mobile-based Application of Document Delivery can support operational activities in providing speed of document delivery to clients, delivery reports can be safe and structured in the database.

2. The application uses a smartphone so it can be easily used by user because it can be carried anywhere and practically in the process of sending documents and filling in delivery reports.

3. Filling out the document delivery report is done by the driver using the features contained in the application so that data is directly stored in the database system, not scattered, and driver doesn't need to provide a written report on the goods delivery to admin staff.

\subsection{Suggestions}

1. Add driver position tracking feature, so that it can track the position of drivers and driver trip recordings.

2. Add signature features to recipient, so that proof of receipt documents is more valid.

3. Security system be improved to avoid the theft and destruction of data.

\section{REFERENCES}

[1] Irsan, Muhammad. 2015. Rancang Bangun Aplikasi Mobile Notifikasi Berbasis Android Untuk Mendukung Kinerja Instansi Pemerintahan. Jurnal. Universitas Tanjungpura.
[2] Shodiq, Amri. 2008. Tutorial Dasar Pemrograman Google Maps API. Tidak diterbitkan.

[3] Wargo, John M. 2015. Apache Cordova 4 Programming. United States. Pearson Education, Inc.

[4] Undang-Undang Nomor 8 Tahun 1997 Pasal 1 angka 2 UUDP Tentang Dokumen Perusahaan

[5] Satika, Nur Dwi. 2014. Sistem Informasi Pengiriman Barang Berbasis Web Dengan Metode Transshipment. Skripsi. Sekolah Tinggi Teknologi Indonesia Tanjungpinang.

[6] Dhika, dkk. 2016. Perancangan Sistem Informasi Jasa Pengiriman Barang Berbasis Web. Jurnal SIMETRIS Vol 7(1) : 51-58.

[7] Satyananda, Darmawan. 2017. Google Map API Service For VRP Solving Application. Prosiding SI MaNIs (Seminar Nasional Integrasi Matematika dan Nilai Islami. Vol 1(1) ; 240-245.

[8] Surahman, Surawijaya. 2017. Aplikasi Mobile Driver Online Berbasis Android Untuk Perusahaan Rental Kendaraan. ULTIMA InfoSys. Vol VIII(1) : 35-42.

[9] Fauzanofami, Luthfi. 2018. Aplikasi Tracking Position Pengiriman Barang Berbasis Android. Skripsi. Universitas Mercubuana. Jakarta.

[10] E.D. Putra, E. Hidayat, and H. Noprisson. 2016. Model Mobile Positioning System Berbasis Android. Skripsi. Jurnal Pseudocode. Vol III (2) : 113-121.

[11] H. Prastiawan, and I. Ranggadara. 2018. Design and Analysis Administration Approval Order System in PT Sysmex Indonesia. International Research Journal of Computer Science (IRJCS). Vol V (Issue 03): 111119.

[12] A. R. Wardhani, D. Susilo, and Y.S Triana. 2018. Design of Service Application for Auto Detailing: A Case Study of Jet Wash Auto Spa Tangerang. International Research Journal of Computer Science (IRJCS). Vol V (Issue 08) : 422-434. 